\title{
Author Correction: Aligning Needs and Capacities to Boost Government Competitiveness
}

Tobin $\operatorname{Im}^{1} \cdot$ Kris Hartley ${ }^{2}$

Published online: 17 June 2019

(C) Springer Science+Business Media, LLC, part of Springer Nature 2019

\section{Author Correction: Public Organization Review https://doi.org/10.1007/s11115-017-0388-0}

The original version of this article unfortunately contained a mistake. The missing acknowledgements of the original article is provided below:

Acknowledgements This work was supported by National Research Foundation of Korea Grant funded by the Korean Government (NRF-2014S1A3A2044898).

The authors' apologizes for this oversight and for any confusion it may have caused.

Publisher's Note Springer Nature remains neutral with regard to jurisdictional claims in published maps and institutional affiliations.

The online version of the original article can be found at https://doi.org/10.1007/s11115-017-0388-0

Kris Hartley

hartley@u.nus.edu

1 Graduate School of Public Administration, Seoul National University, 151-742 Gwanak-ro, Gwanak-gu, Seoul, South Korea

2 Department of City and Regional Planning, Cornell University, 213 Sibley Hall, Ithaca, NY 14853, USA 